\title{
A Case of Primary Septated Mucocele of Maxillary Sinus
}

\author{
Juyong Chung, Young Chang Sim, Dam Ho Lee, and Jae Hoon Lee \\ Department of Otolaryngology-Head and Neck Surgery, Institute of Wonkwang Medical Science, College of Medicine, \\ Wonkwang University, Iksan, Korea
}

\section{상악동에서 발생한 격벽으로 나누어진 원발성 점액낭종 1 예}

정주용 · 심영창 · 이담호 · 이재훈

원광대학교 의과대학 이비인후과학교실, 원광의과학 연구소

Received July 31,2016

Revised September 22, 2016

Accepted October 4, 2016

Address for correspondence

Jae Hoon Lee, MD

Department of Otolaryngology-

Head and Neck Surgery,

Institute of Wonkwang Medical

Science, College of Medicine,

Wonkwang University,

895 Muwang-ro, Iksan 54538, Korea

Tel $+82-63-859-1441$

Fax $+82-63-841-6556$

E-mail leejaehoon64@gmail.com
Paranasal sinus mucoceles are benign non-neoplastic condition characterized by cystic expansion. They are classified into primary and secondary mucoceles by known causes. Most mucoceles are located in the frontal and anterior ethmoid sinuses and they involve the frontoethmoial region, expanding to the region of the orbit, leading to the ocular symptoms. The primary maxillary sinus mucoceles are not common, whereas secondary ones such as postoperative maxillary sinus mucoceles (POMMs) developing after Caldwell-Luc operation are pretty common. POMMs have often multiple septated mucoceles. However, most of the primary maxillary sinus mucoceles are an expansile and cystic mass of maxillary sinus with medial bulging. We present a case of primary septated mucocele in the maxillary sinus of a 36-year-old male who underwent revision surgery.

Korean J Otorhinolaryngol-Head Neck Surg 2016;59(12):865-8

Key Words Maxillary sinus · Mucocele.

\section{서 론}

부비동 점액낭종은 부비동 내에 점액이 저류되는 확장성 낭종으로 부비동 개구부 점막의 염증성 폐쇄가 가장 흔한 원 인이다. 상악동에 생긴 점액낭종은 Caldwell-Luc 수술 후 10 20년 이상 지나서 발생하는 술 후 상악동 점액낭종(postoperative maxillary mucocele, $\mathrm{POMM}$ )이 대부분 상악동 점 액낭종의 원인을 차지한다. 외상이나 코 수술 기왕력이 없이 발생하는 상악동의 원발성 점액낭종은 상대적으로 드물다. $\mathrm{POMM}$ 은 간혹 격벽으로 인해 다발성 점액낭종이 관찰되는 반면 대부분 원발성 점액낭종은 팽창된 상악동 병변으로 관 찰되며 격벽을 동반한 다발성인 경우는 매우 드물다.,2)

본 저자들은 일측성으로 발생한 심한 안면 통증과 비폐색 을 주소로 내원하여 상악동의 원발성 점액낭종으로 진단되 어 조대술 후에도 증상이 소실되지 않아 재시행한 부비동 단 층촬영에서 상악동 내에 격벽으로 나누어진 또 다른 점액낭
종을 발견하여 재수술을 한 예를 치험하여 문헌고찰과 함께 보고하는 바이다.

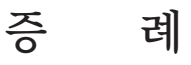

36세 남자 환자가 한 달 전부터 시작되어 점점 심해지는 좌 측 안면 통증과 비폐색을 주소로 내원하였다. 과거에 외상 기왕력 및 부비동염으로 치료를 받거나 코 수술을 받은 적은 없었으며 콧물, 코피 등 특이한 코 증상과 유루증, 안와 통증 및 시력 이상과 같은 안과적인 증상을 호소하지 않았다. 비 내시경 검사에서 좌측 중비도에 돌출된 종물 소견 외에 특이 한 소견은 관찰되지 않았으며, 조영 증강 부비동 전산화단층 촬영에서 좌측 상악동에 조영 증강되지 않는 팽창성의 종물 이 있었으며, 상악동의 내측 벽이 비중격에 닿을 정도로 비 강 내로 변형되었고 좌측 안와저 골벽의 일부가 파괴되었다 (Fig. 1). 
Fig. 1. Preoperative CT scans of the first surgery. Axial CT image (A) shows an expansile, homogenous, and cystic mass of the left maxillary sinus. Coronal CT image $(B)$ shows the mass expanding into the inferior portion of the left orbit.
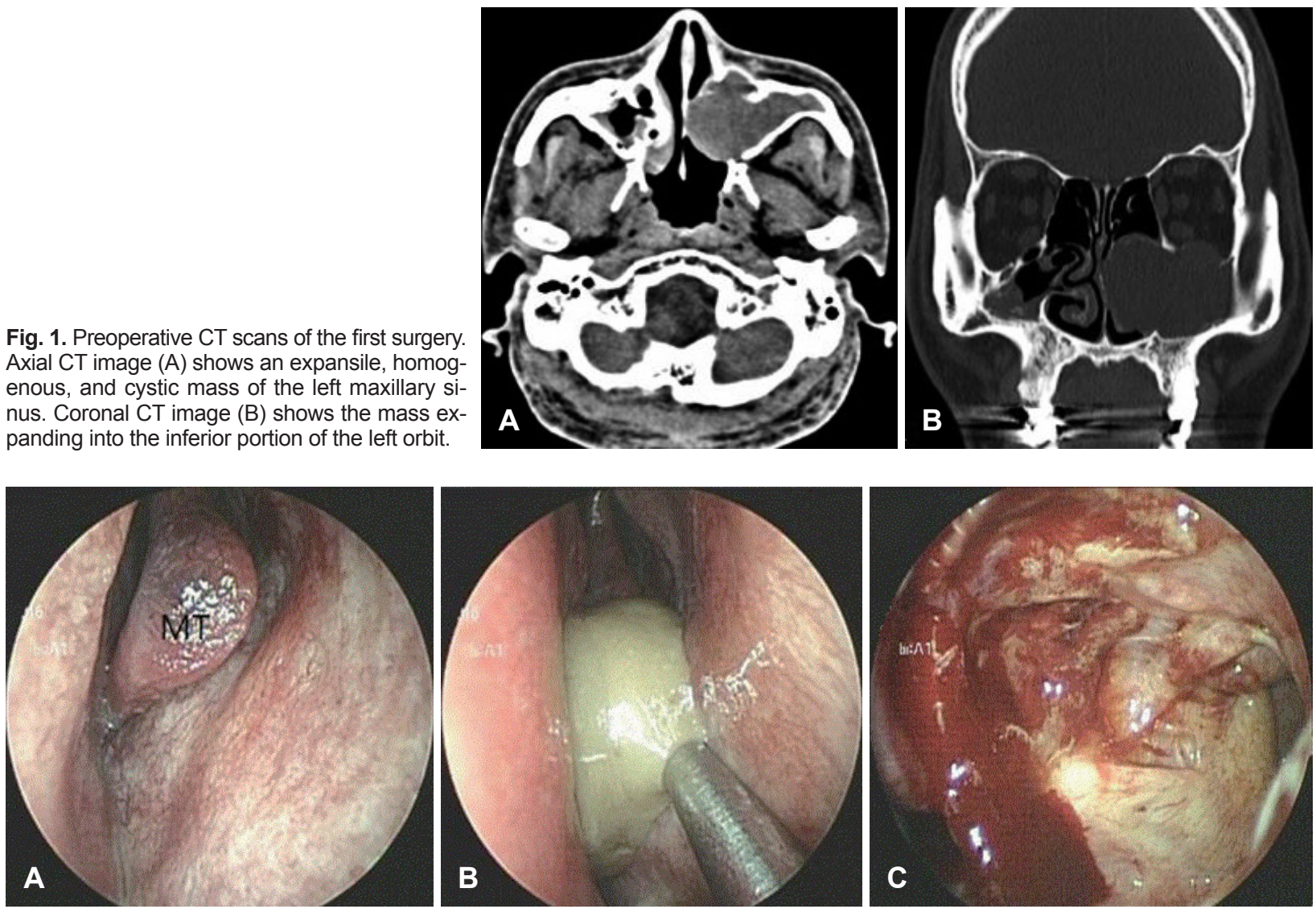

Fig. 2. Intraoperative endoscopic pictures of the first surgery. The mass with medial bulging (A). Yellowish-colored mucoid discharge within the mass (B). Cleared the maxillary sinus after middle meatal antrostomy (C). MT: middle turbinate.

Fig. 3. Preoperative CT scans of the second surgery. Coronal CT (A) and axial CT (B) images show the remained mass (arrow) in the anterior portion of the left maxillary sinus.
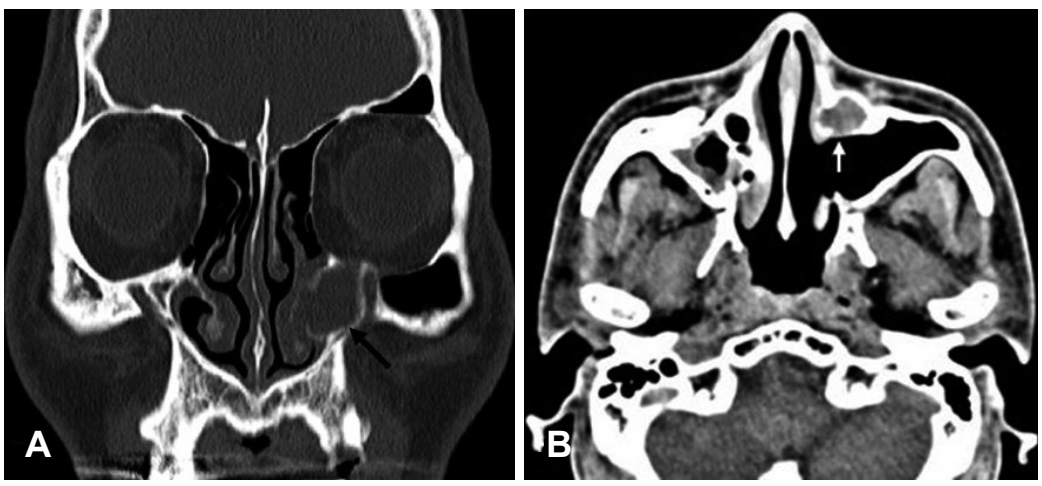

Fig. 4. Intraoperative endoscopic pictures of the second surgery. Yellowish-colored mucoid discharge from the bulging portion of the left inferior meatus $(A)$. The view of the well-marsupialized cavity after inferior meatal antrostomy, and removing the septation which is placed between the two masses (B) (asterisk: the marsupialized cavity after the first surgery). IT: inferior turbinate.

이런 소견을 종합하여 상악동 내의 원발성 점액낭종을 의 심하였다. 전신마취하에 비내시경을 이용하여 종물에 대한 조대술을 시행하였다. 좌측 중비도에 돌출된 종물에 낫 형태 칼(sickle type knife)로 절개를 가한 후 연부조직 분쇄기를 이 용하여 절개부위를 크게 열었으며, straight cutting forceps와 back bitting forceps를 이용하여 상악동 자연공에서 후방 천 문(posterior fontanelle) 부위까지 커다란 통로를 만들어 주 는 경중비도 상악동개방술(middle meatal antrostomy, MMA) 을 하였으며 종물 안에는 점액 농성 분비물이 가득 차 있었 다(Fig. 2). 안구를 눌러서 상악동 내 안와저 골부의 파괴를 확인하였는데 덮고 있는 상악동 점막 손상은 없었다. 수술 중 채취한 점액 농성 분비물의 세균 배양검사에서 Staphylococcus epidermidis가 배양되었다.

환자는 특별한 합병증 없이 수술 3일 후 퇴원하였다. 수술 2주 후 외래 내원 시 MMA 부위는 잘 열려 있었으며 환자는 좌측 코막힘을 더는 호소하지 않았다. 그러나 좌측 코 입구, 이상구(piriform aperture) 및 위 입술 부위에 감각 이상 그리 고 통증을 호소하였으나 수술로 인한 일시적인 통증으로 생 각하여 경과 관찰하였다. 수술 3 주 후 재차 외래 내원 때 통증 이 더욱 심해진다고 호소하여 부비동 전산화단층촬영을 다 시 시행하였다. 그 결과 좌측 상악동의 전방에 남아 있는 작 은 크기의 종물이 관찰되었고 3주 전에 $\mathrm{MMA}$ 를 통한 조대 술을 했던 점액낭종과 격벽으로 나누어져 있음을 확인하였 다(Fig. 3).

상악동 내의 남아 있는 점액낭종 진단하에 비내시경을 이 용하여 종물에 대한 조대술을 시행하였다. 좌측 하비도 입구 에 약간 돌출된 부위에 절개를 가한 후 연부조직 분쇄기 및 straight cutting forceps를 이용하여 경하비도 상악동개방술 (inferior meatal antrostomy, IMA)을 하였다. 종물 안에는 일차 수술 때와 같은 점액 농성 분비물이 있어 제거한 후 두 낭종 사이에 있던 격벽을 제거하여 하나의 큰 공간으로 만들 었다(Fig. 4). 점액 농성 분비물에서 세균은 배양되지 않았다. 환자는 재수술 2 일 후 퇴원하였으며, 재수술 1 주 후 외래 내 원 시 더는 통증을 호소하지 않았으며 감각 이상은 수술 3주 에 걸쳐 서서히 회복되었다.

\section{고 찰}

부비동 점액낭종은 전두동, 사골동, 상악동, 접형동과 같은 모든 부비동에서 발견될 수 있으며 발생에 선천성 인자, 점액 저류, 감염, 염증, 외상 등의 많은 요소가 관여할 수 있다.2) 점 액낭종은 원발성과 이차성으로 분류할 수 있는데 외상의 기 왕력, 비부비동 종양 혹은 비용을 동반한 심한 부비동염 혹
은 부비동염 수술의 기왕력이 있으면 이차성에 해당한다.

Hasegawa 등 3 은 132 명의 상악동 점액낭종 중에서 131명이 Caldwell-Luc 수술 후에 발생한 이차성 상악동 점액낭종으 로 보고했다. Lee와 Lee ${ }^{4}$ 는 33명의 원발성 점액낭종과 60명 의 이차성 점액낭종을 분석한 결과 일차성은 사골동(45.5\%), 상악동(18.2\%) 순으로, 이차성은 상악동(80\%), 사골동(13.3\%) 순으로, 상악동에서는 일차성 점액낭종보다 이차성인 경우 가 많았다. Gardner와 Gullane에 에 따르면 POMM은 CaldwellLuc 수술 후 본래의 상악동 배출공으로 환기 및 배액이 되 는 부분과 그렇지 못한 두 부분으로 섬유성 격벽에 의해 나 뉘어 환기 및 배액이 이루어지지 않는 부분에서 점액이 축적 되어 발생한다고 하였다.

Song 드ㅇㅣㅡㄴ 10 년 동안 상악동 점액낭종으로 진단된 경우에 서 외상 또는 부비동 수술의 기왕력이 없는 원발성인 경우는 7 명으로 이차성보다 상대적으로 드물었다. 상악동 원발성 점 액낭종만을 분석한 결과 내원 당시 환자가 호소한 증상은 비 폐색, 콧물, 안면부 통증 순이었고, 부비동 전산화단층촬영 에서 상악동의 내측벽이 비강 내로 팽창된 경우가 많이 관찰 되었으며 드물게 상악동 상벽과 후벽의 골 파괴와 더불어 안 와저를 침범한 소견도 있었다. ${ }^{1)}$ 원발성인 경우 격벽을 동반한 점액낭종은 없었다. 이차성 상악동 점액낭종인 $\mathrm{POMM}$ 의 증 상은 Caldwell-Luc 수술로 인해 상악동 전벽에 결손이 있어 그 부위를 통한 협부의 종창, 종물 및 통증이 흔한 증상이 고, 원발성에서는 흔한 증상인 비폐색은 드물다. ${ }^{2,6}$

점액낭종과 감별해야 하는 질환으로 콜레스테롤 육아종, 종양 등이 있다. 점액낭종과 콜레스테롤 육아종의 관계에 있 어 부비동의 자연공의 폐쇄 후에 출혈이 동반되는 경우에는 콜레스테롤 육아종이 발생하고 출혈이 없는 경우에 점액낭종 이 발생할 수 있다고 하였다. ${ }^{7)}$ 부비동 전산화단층촬영에서 상 악동에서 발생하는 점액낭종과 콜레스테롤 육아종은 상악 동을 꽉 채우는 팽대된 경우가 많으며 두 질환을 감별하는 특 징적인 방사선학적 소견은 없다. 자기공명 영상에서는 부비동 내 점액질의 단백질 농도에 따라 다양한 양상을 보인다. T1 강조영상과 T2 강조영상 모두에서 콜레스테롤 결정체와 헤모 글로빈 분해 산물로 인해 고신호 강도를 보이는 특징을 보이 는 경우 좀 더 특이적으로 콜레스테롤 육아종의 진단에 도움 을 줄 수 있다. ${ }^{8)}$

$\mathrm{POMM}$ 의 경우 많은 예에서 IMA로 해결될 수 있으나 격벽 을 동반한 다발성인 경우 낭종의 일부가 상악동 내에서 지나 치게 외측 혹은 상측에 존재한 경우 Caldwell-Luc 접근법과 함께 내시경을 이용한 접근이 필요하다. ${ }^{2}$ 그러나 상악동 원발 성 점액낭종은 대부분 팽창된 상악동 병변으로, $\mathrm{MMA}$ 와 함 께 필요한 경우 IMA를 추가하는 비내 내시경 접근만으로도 


\section{충분히 해결된다. ${ }^{1)}$}

본 증례는 일차 수술 때 상악동 내 점액낭종들 사이에 격벽 확인이 쉽지 않아 상악동 전방 부위에 있는 다른 하나의 점액 낭종이 남아 재수술을 통해 해결하였다. 이 증례를 통해 상악 동의 원발성 점액낭종인 경우에도 드물지만, 격벽으로 나누어 진 점액낭종의 가능성을 염두에 두어야 한다.

\section{REFERENCES}

1) Song HM, Park HW, Chung YS, Jang YJ, Lee BJ. Primary mucoceles of the maxillary sinus. Korean J Otolaryngol-Head Neck Surg 2006; 49(1):47-51.

2) Lee JH. A clinical analysis of postoperative cheek cyst: 10-year experience. J Clinical Otolaryngol 2012;23(1):79-84.

3) Hasegawa M, Saito Y, Watanabe I, Kern EB. Postoperative mucoceles of the maxillary sinus. Rhinology 1979;17(4):253-6.

4) Lee KC, Lee NH. Comparison of clinical characteristics between primary and secondary paranasal mucoceles. Yonsei Med J 2010; 51(5):735-9.

5) Gardner DG, Gullane PJ. Mucoceles of the maxillary sinus. Oral Surg Oral Med Oral Pathol 1986;62(5):538-43.

6) Mendelsohn DB, Glass RB, Hertzanu Y. Giant maxillary antral mucocele. J Laryngol Otol 1984;98(3):305-10.

7) Milton CM, Bickerton RC. A review of maxillary sinus cholesterol granuloma. Br J Oral Maxillofac Surg 1986;24(4):293-9.

8) Bütler S, Grossenbacher R. Cholesterol granuloma of the paranasal sinuses. J Laryngol Otol 1989;103(8):776-9. 